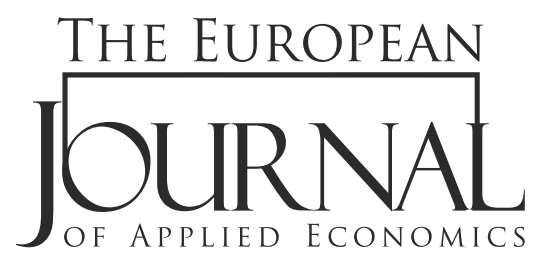

EJAE 2019, 16(2): 95-108

ISSN 2406-2588

UDK: $338.1(669)$

330.55

DOI: 10.5937/EJAE16-20251

Original paper/Originalni naučni rad

\title{
THE RISING GOVERNMENT EXPENDITURE IN NIGERIA: ANY INFLUENCE ON GROWTH?
}

\section{Segun Subair Awode}

Nigerian Institute of Social and Economic Research (NISER)

Nigeria

\begin{abstract}
:
This study attempts to examine whether government expenditure in Nigeria has had any influence on growth in the economy. The study focuses primarily on capital and recurrent types of government expenditure, and these were regressed against the real gross domestic product. Secondary time series data ranging from 1981 to 2016 obtained from the CBN Statistical Bulletin were used. Having established that the series were co-integrated in the long run through the Cointegration technique of Johansen, the study then used the error correction and Granger causality techniques to achieve its objectives. Results indicated that recurrent expenditure exerts a significant positive influence on real GDP, while the influence of capital expenditure on real GDP turned out negative. The Granger causality test revealed that both capital and recurrent expenditures Granger cause real GDP. The study, therefore, advocates for a strong monitoring and evaluation system of the way in which government funds, especially those intended for capital projects, are being used, so as to bring about a meaningful influece on the economy.
\end{abstract}

\section{Article info:}

Received: January 21, 2019

Correction: February 08, 2019

Accepted: April 06, 2019

\section{Keywords:}

capital expenditure, economic growth, error correction mechanism, Granger causality, gross domestic product 


\section{INTRODUCTION}

There is no denying the fact that governments in every nation, developed or developing, are charged with carrying out some statutory roles in the country, some of which include (but not limited to) protecting the citizenry against domestic and external attacks, catering to the welfare needs, and providing social services for its people. To say that carrying out these (and other equally important) roles requires a huge amount of spending by the government is no exaggeration.

Government expenditure in Nigeria, as noted by Iheanacho (2016), has been rising rapidly, with such recurring increase evidenced in almost all the sectors of the economy. A cursory breakdown of the 2019 appropriation bill of Nigeria shows that the Federal Government seeks to spend USD 24.41 billion, which is about $2.5 \%$ higher than the 2018 estimates, whose proposed size of USD 23.8 billion was $16 \%$ higher than the 2017 estimates. A huge chunk of this (2019 appropriation bill) was proposed to be spent on recurrent expenditure, which stood at USD 11.18 billion; capital expenditure at USD 5.6 billion; and debt servicing at USD 5.92 billion, on its own representing about a quarter of the total estimate. The capital expenditures alone stand at $23 \%$ of the total budget, while its Siamese twin (recurrent expenditures) stands at $45.75 \%$.

Given that the government's major concern, as noted earlier, is primarily the welfare and living conditions of the masses, which statutorily determines the government's spending pattern. A colossal amount of concern keeps lingering over the skyrocketing and superfluous government spending in Nigeria, yet the masses keep languishing in abject poverty (Iheanacho, 2016; Oyinlola \& Akinnibosun, 2013). It becomes even more worrisome to discover that many past administrations have spent so much on capital and recurrent expenditures, yet the results remain infrastructural gaps and impoverishments (Oteng-Abayie, 2011; Adekunle, 2007). Bitter enough, recurrent expenditures now outstrip capital expenditures with almost double its size (Njoku et al.2014). One big question that comes to mind is "where exactly is the money going if not to the betterment of people's lives and engineering growth of the economy?"

Empirical findings of the effects of federal government expenditures on growth in the Nigerian context have been mixed and inconsistent. In relation to the issues already raised, extant studies, such as Njoku et al. (2014), Udoffia and Godson (2016), Akonji et al. (2013) and many others reported that recurrent expenditure impacts growth positively in Nigeria, while the findings of studies, such as Aigheyisi (2013) and Ayinde et al. (2015) suggested otherwise. In fact, by confirming the inconsistencies among extant studies, Ayinde et al. (2015) suggested a further re-evaluation and reassessment of the direction of causal impact between recurrent expenditure and economic growth.

Further important empirically misunderstood evidence about the growing volume of government spending and economic growth in Nigeria is the argument on Wagner's Law, which argued that long-run tendencies exist for public expenditure to grow relatively to the growth of the economy, and that, as the economy develops over time, the activities and functions of the government would increase. Many extant studies, such as Akonji et al. (2013) supported this while some others like Awode and Akpa (2018) and Olayungbo and Olayemi (2018) refute the claim, but by considering the poverty level of the people, such increases in government spending, which are potentially informed by the catastrophic occurrences mentioned in the background, may not suggest the true growth in economy. Therefore, to provide empirical evidence for solving these observed research problems, the need to embark on this current study remains pertinent. It is against these backdrops that the study draws its motivation to investigate empirically how the Nigerian economy (in terms of real GDP) has fared following several periods of huge budgetary allocations. 
Having introduced the focus of the paper in this section, the literature was extensively reviewed in the second section; methodological issues were dealt with in section three, section four presents the results and their discussions, while section five concludes the paper.

\section{LITERATURE REVIEW}

Many studies have been carried out in the past, using several approaches and methodologies, in the bid to address empirically how public spending impacts the growth of the Nigerian economy. One such study is Aigheyisi (2013) whose work was conducted to investigate the impact of government expenditure on Nigeria's economy from 1980 to 2011. The study used a multiple regression analysis and employed a disaggregated data on capital and recurrent expenditures. The study's findings indicate that the impacts of the variables on GDP were statistically insignificant. However, they became significant following a one-period lag, with the impact of recurrent expenditure negative, while that of capital expenditure was positive. Similar to this, Akonji et al. (2013) also did a study to investigate the linkages between the different components of government expenditure and real gross domestic product for Nigeria. The techniques employed both the Granger causality and Error Correction techniques. The result showed that the link between capital expenditure and real GDP is in consonance with Wagner's law, while that of total recurrent expenditure and real GDP proved bi-causal. However, the causation from recurrent expenditure to real GDP is stronger.

Iheanacho (2016) also carried out a study to empirically determine the quantum of contributory impact government expenditure has on growth in Nigeria using a disaggregated data approach for the period between 1986 and 2014. The study made a distinct contribution by controlling for influence revenue from non-oil sources. Findings revealed negative and positive relationship between recurrent expenditure and economic growth in the short and long run, respectively, in Nigeria. However, the results indicated a long-run negative relationship between capital expenditure and growth in Nigeria. Similarly, Ayinde et al., (2015) did a study to unravel the relationship among public expenditure, revenue, and economic growth in Nigeria from 1981 to 2011 using the Co-integration, Error Correction Mechanism and Combined Estimators Analysis Approach. Findings showed evidence of a long run relationship among the variables, while it was further revealed that the effects of capital expenditure, oil revenue, federation account, and federal retained revenue on growth were positive in Nigeria.

Njoku et al. (2014) also did a study to determine the effect of public expenditures on economic growth in Nigeria from 1961 to 2013 by adopting a quantitative research methodology. Findings showed that capital expenditure on administration, recurrent expenditure on social and community services, as well as recurrent expenditure on economic services are growth-enhancing; while economic expenditure, capital transfers, recurrent expenditure on administration, and recurrent expenditure on transfers retract the growth of the economy in Nigeria.

Oyinlola and Akinnibosun (2013) also contributed to the empirics on the public expenditure-growth nexus in Nigeria from 1970 to 2009 by using the Gregory-Hansen structural break cointegration to analyze a disaggregated public expenditure, and the result affirms the existence of Wagner's law, while also revealing a structural break in 1993, accounting for the political upheaval of the annulled general election in the country then. 
Udoffia and Godson (2016) did a study to determine the impact of government expenditure on Economic Growth in Nigeria from 1981 to 2014. Using time series data sourced from the CBN Statistical Bulletin, findings showed that both capital and recurrent expenditures of the federal government have a positive effect on economic growth in Nigeria. Still in the effort to address how government spending affected economic growth in Nigeria, Chude and Chude (2013) also did a study to investigate the effects of public expenditure on economic growth in Nigeria over a period stretching from 1977 through 2012, using disaggregated data and employing the Error Correction Model (ECM) as the technique of analysis. Findings from the study indicate that, in the long, expenditure on education influences economic growth reacts positively to education expenditure in Nigeria.

Slightly different from the foregoing nature of studies, Ayuba (2013) concentrated on the social expenditure-growth nexus in Nigeria between 1990 and 2009. The study applies VECM-Based Causality and the findings suggested that economic growth causes changes in health expenditure, and that there is a unidirectional causality running from economic growth to health expenditure, thereby supporting Wagner's Law. The results further revealed that the economic growth Granger causes both education and aggregate social expenditures in Nigeria.

Kairo et al. (2017) examined the impact of government spending on human capital development using secondary set of data from 1990 to 2014 and employing the Autoregressive Distributed Lag (ARDL) Model Approach as the technique of analysis. Findings showed that a long run relationship exists between expenditure and human development index. The results further demonstrated that government expenditure has remained positive, but to a very large extent insignificant to human capital development in Nigeria.

Elsewhere, Adil, Ganaie and Kamaiah (2017) carried out an empirical investigation into Wagners's hypothesis in India from 1970 to 2013 employing the Autoregressive Distributed Lag (ARDL) Model. The study showed a long-run cointegration existed between economic growth and government expenditure, but evidence for Wagner's law was not present.

Chow, Cotsomitis and Kwan (2002) conducted a study in the UK to show that relying on a bivariate Wagner model (economic growth regressed on government expenditure) was not adequate to understanding the long-run relationship between the variables using time series data from 1948 to 1997. The study introduced a third variable- money supply-, and showed that a long-run equilibrium existed between government spending and economic growth. The conducted Granger causality test indicated a one-way direction of causal effect from both income and money supply to government expenditure.

Chang, Liu and Caudill (2004) re-examined the existence Wagner's law using its five different versions across three emerging countries of Asia and seven other industrialized economies. The study employed the Johansen cointegration test and error correction mechanism (ECM), and results showed a one-way causation that runs from economic growth to government expenditure in South Korea, Taiwan, Japan, the United Kingdom, and the United States, thus validating Wagner's law in these countries. The other countries- Australia, Canada, New Zealand, South Africa, and Thailand posted no evidence of causation effect from economic growth to public spending. The study also confirmed a long-run cointegration existing between the variables.

Abbasov and Aliyev (2018) tested Wagner's and Keynes' law in nine former Soviet Union countries from the first quarter of 2000 to the third quarter of 2017. The study adopted the Autoregressive Distributed Lag (ARDL) Model of estimation. Findings from the study validated Wagner's law for Latvia, Lithuania, Uzbekistan, Georgia, Kyrgyzstan, and Ukraine, while the Keynesian hypothesis was validated for Estonia, Uzbekistan, Azerbaijan, Kyrgyzstan, and Moldova in the long run. Unlike Chow, Cotsomitis and Kwan (2002) and Chang, Liu and Caudill (2004), where a unidirectional relationship was established from income 
to public expenditure, this study found a short-run bi-causal relationship in all of the countries studied except Lithuania and Kyrgyzstan.

Antonis, Constantinos and Persefoni (2013) compared Wagner's and Keynesian law in pre-World War II Greece with data from 1833 to 1938. In addition to the empirical analysis using the Autoregressive Distributed Lag (ARDL) estimation method, the study also conducted a test to determine the presence or otherwise of structural breaks in the series. Findings from the study showed that economic growth reacts positively to public spending, thus confirming Wagnerćs law in Greece. On the other hand, the Keynesian hypothesis was valid for the entire sample period (1833-1938), but not so for the sub-sample period of 1881-1938.

Olayungbo and Olayemi (2018) conducted a study whose major focus was to unravel the dynamic relationship existing among non-oil revenue, government spending, and economic growth in Nigeria using secondary data ranging from 1981 to 2015 . The study employed the error correction, impulse response function as well as granger causality techniques to achieve its stated objective. Results indicate that government spending impacts the economy negatively while the effect of non-oil revenue on the economy was positive both in short and long run. However, the granger causality test revealed a unidirectional causality running from government spending to both non-oil revenue and economic growth in Nigeria.

Awode and Akpa (2018) conducted a study to test the existence or otherwise of Wagner's law in Nigeria in the short and long run. The study applied the autoregressive distributed lag technique and controlled for structural breaks within the period 1981-2016. The study noted a negative and insignificant effect relationship between government expenditure and economic growth, thus refuting the claim of Wagner's law in Nigeria. The effect of oil export earnings was controlled for, and it was found to influence government spending positively both in the short run and long run. The study, therefore, noted the need for the economy to be more diversified into more labour-intensive sectors to increase output per worker, and to ensure that government expenditure is based more on tax earnings than on oil export earnings.

Babatunde (2018) carried out a study to determine how the government's infrastructural spending relates to the growth of the Nigerian economy using data series from both primary and secondary sources from 1980 to 2016. The primary data for the study was obtained using statistical random sampling for the sample selection, and analyzed using descriptive statistics. The secondary data were analyzed by employing vector error correction mechanism. Results of the study indicate that public spending on the transport, communication, education, and health sectors impacts economic growth directly in Nigeria. However, the government's agricultural and natural resources spending indirectly impact the economy. An element of fiscal illusion was further revealed in the sense that agriculture and natural resources sector in Nigeria receive more funding from the private sector than from the government.

The present study, therefore, attempts to both examine the growth effect of rising government expenditure in Nigeria by disaggregating government expenditure broadly into its capital and recurrent categories as well as establish whether any causal relationship exists between government expenditure and economic growth in Nigeria. 


\section{METHODOLOGY}

\section{Model Specification}

The model used in this study was adapted from Akonji et al., (2013) and Udoffia and Godson's (2016) studies in an attempt to replicate their efforts to test Wagner's Law and test the true empirical state of the Keynesian theory on connectivity between the variables employed in the study.

To begin with, the model first considers the simple purport of endogenous growth model, which specifies that, for a nation to achieve a growth in its state of economy, it must invest in human capital relative to its stock of labour. By this notion, we have:

$$
R G D P=f\left(A K^{a} L^{b}\right)
$$

Where

$R G D P$ represents the Real Gross Domestic Product;

$A$ represents the total factor productivity, which incorporates the export trade (ET);

$K$ is the human capital; and

$L$ is labour.

By relating with Wagner's law, which specifies that an economic growth can be achieved through government spending, now, given that;

Total Government Spending $=f$ (Government Expenditure $)$

In equation (2), the components of government spending will be limited to capital and recurrent expenditures only.

By combining equations (1) and (2), we have,

$R G D P=f$ (capital expenditue, recurrent expenditure)

In mathematical terms, equation (3) above can be linearized as thus;

$$
R G D P=\beta_{u}+\beta_{1} C E+\beta_{2} \mathrm{RE}
$$

Where

$\beta_{u}$ represents the intercept (constant term),

$\beta_{1}$ and $\beta_{2}$ represent the parameters of the model, and

CE represents Capital Expenditures (in billions),

$R E$ represents total Recurrent Expenditure (in billions)

In $\log$ and econometrics forms, equation (4) becomes;

$$
i n R G D P=\beta_{u}+\beta_{1} C E+\beta_{2} i n \mathrm{RE}+\mathrm{e}
$$

Where

In represents the natural logarithm properties,

$e$ represents the Residual or the Error Term 
Based on economic theory - specifically Wagner's Law, a direct positive relationship is expected between government expenditures (capital and recurrent) and real GDP. It is assumed that more government spending will bring about an increase in real GDP.

Time series data from 1981 to 2016 were used for this study. Specifically, the data used was on: capital and recurrent components of federal government expenditures, and the data on real gross domestic product (RGDP), which proxies economic growth. These datasets were obtained from the CBN Statistical Bulletin, and analyzed using the statistical package E-views 9.

\section{Results and Discussion}

Table 1: Descriptive Statistics

\begin{tabular}{cccc}
\hline & LOG(RGDP) & LOG(CE) & LOG(RE) \\
\hline Mean & 24.96960 & 4.789211 & 5.372348 \\
\hline Median & 24.53515 & 5.542390 & 5.645415 \\
\hline Maximum & 27.06539 & 7.049946 & 8.320768 \\
\hline Minimum & 23.48328 & 1.411011 & 1.558313 \\
\hline Std. Dev. & 1.140242 & 1.963357 & 2.320157 \\
\hline Skewness & 0.673019 & -0.519424 & -0.303626 \\
\hline Kurtosis & 2.014776 & 1.702326 & 1.694984 \\
\hline Jarque-Bera & 4.173729 & & 3.107734 \\
\hline Probability & 0.124076 & 4.144743 & 0.211429 \\
\hline Sum & & 0.125887 & 193.4045 \\
\hline Sum Sq. Dev. & 898.9055 & & 188.4095 \\
\hline Observations & 45.50532 & 134.9169 & 36 \\
\hline
\end{tabular}

Source: Author, 2019

From Table 1, which shows the result of the descriptive statistical properties of the variables employed in the study, it was revealed that all the variables were leptokurtic in nature, since their Kurtosis values were greater than 3. However, while real GDP skewed positively, implying that real GDP exhibited more of increasing values over the period under review, both capital and recurrent expenditures showed negative skewness, meaning that both capital and recurrent expenditures exhibited more of decreasing values over the period under review. Furthermore, the Jarque-Bera statistic, which is a formal test of normality, reveals that all the variables were normally distributed, since the p-values associated with their Jarquw-Bera statistic were not statistically significant at $5 \%$ level. 
Table 2: Unit Root Test Result

\begin{tabular}{cccc}
\hline & Augmented Dickey Fuller (ADF) Test & Status \\
\hline Variables & Level & 1st Difference & $\mathrm{I}(1)$ \\
\hline LOG(RGDP) & 1.4213 & -5.2116 & $\mathrm{I}(1)$ \\
\hline LOG(CE) & 1.6216 & -5.0620 & $\mathrm{I}(1)$ \\
\hline LOG(RE) & 3.2341 & -2.2171 & \\
\hline Critical Values & & & \\
\hline $1 \%$ & -2.6326 & -2.6347 & -1.9510 \\
\hline $5 \%$ & -1.9507 & -1.6109 & \\
\hline $10 \%$ & -1.6111 & & \\
\hline
\end{tabular}

Source: Author, 2019

The Augmented Dickey Fuller (ADF) test was employed to assess the unit root properties of the variables and the emanated results, as shown in Table 2, and indicated that all the variables, which were not stationary at levels, became stationary after first differencing which means that the order of integration of all the variables is order one. This implies that an element of possible long-run relationship exists among the variables. This, therefore, requires further investigation of long-run co-movement among the variables. In carrying this out, the Johansen co-integration technique comes in handy.

Table 3: Johansen Co-integration Result

\begin{tabular}{lllll}
\hline Hypothesized & Trace & $\mathbf{0 . 0 5}$ & Max-Eigen & $\mathbf{0 . 0 5}$ \\
\hline No. of CE(s) & Statistic & Critical Value & Statistic & Critical Value \\
\hline $\mathbf{r} \leq \mathbf{0}$ & $40.71352^{\star}$ & 29.79707 & $24.08978^{\star}$ & 21.13162 \\
\hline $\mathbf{r} \leq \mathbf{1}$ & $16.62375^{\star}$ & 15.49471 & 12.40533 & 14.26460 \\
\hline $\mathbf{r} \leq \mathbf{2}$ & $4.218411^{\star}$ & 3.841466 & $4.218411^{\star}$ & 3.841466 \\
\hline
\end{tabular}

${ }^{*}$ denotes rejection of the hypothesis at the 0.05 level

${ }^{* *}$ MacKinnon-Haug-Michelis (1999) p-values

Source: Author, 2019

The result of the Johansen co-integration has been presented in Table 3 and this result revealed that a long-run co-movement exists among the variables. This is due to the fact that the Trace statistic revealed three cointegrating equations, while the Max-Eigen statistic showed two, indicating that the variables employed in this study are cointegrated in the long run. By putting this into better perspective, the result provided evidence of a convergence relationship among the variables in the long run. 
Table 4: Error Correction Mechanism (ECM) Results

\begin{tabular}{ccccc}
\hline \multicolumn{5}{c}{ Dependent Variable: LOG(RGDP) } \\
\hline \multicolumn{5}{c}{ Method: Least Squares } \\
\hline Variable & Coefficient & Std. Error & t-Statistic & Prob. \\
\hline LOG(CE) & -0.353330 & 0.112256 & -3.147534 & 0.0036 \\
\hline LOG(RE) & 0.721135 & 0.095457 & 7.554587 & 0.0000 \\
\hline C & 22.75126 & 0.145057 & 156.8433 & 0.0000 \\
\hline ECM(-1) & -0.811908 & 0.083859 & -9.681768 & 0.0000 \\
\hline R-squared & 0.934265 & \multicolumn{2}{c}{ F-statistic } & 146.8636 \\
\hline Adjusted R-squared & 0.927904 & Prob(F-statistic) & 0.000000 \\
\hline Durbin-Watson stat & 1.837085 & \multicolumn{3}{c}{} \\
\hline
\end{tabular}

Source: Author, 2019

The results presented in Table 4 refer to the estimates of the impact of federal government expenditures on economic growth in Nigeria over the 1981-2016 period using the Error Correction Mechanism. The results indicated that capital expenditure of the government contributes negatively to the growth of the economy. Specifically, a 1\% increase in capital expenditure led to 35\% reductions in the growth of the economy. The implication of this is that, despite the huge yearly budgetary allocations for capital expenditures, the statutory role of the government in ensuring a growing economy has not been achieved. This may be due to either ineffective usage and mismanagement of such budgeted funds, or partial or total embezzlement and looting of the budgeted funds by government officials, or both. Moreover, by the nature of capital expenditures, it may take several years for them to start to yield positive impacts on the economy.

However, the result showed that recurrent expenditure wields a positive and significant impact on the growth of the economy. A $1 \%$ increase in recurrent expenditure increases the growth of the economy by approximately $72 \%$. The implication of this is that recurrent expenditure is growth-enhancing in Nigeria.

The results also indicate that the error correction coefficient is negative and significant, which implies that a long-run co-movement exists among the variables. Specifically, a short-run shock to the system has the potential of returning the series to about $81 \%$ of its equilibrium level in the preceding year. This is a very high speed of adjustment!

The model has a good fit, as about $93 \%$ of variations in real GDP are explained by both capital and recurrent expenditures. This is buttressed by the F-statistic, which is statistically significant at $1 \%$ level. Finally, the model does not suffer a serial correlation problem.

Table 5: Granger Causality Result

\begin{tabular}{|c|c|c|c|}
\hline Null Hypothesis & F-Statistic & Prob. & Granger Causality \\
\hline LOG(CE) does not Granger Cause LOG(RGDP) & 11.6447 & 0.0018 & \multirow{2}{*}{$\begin{array}{c}\text { Unidirectional causality } \\
\qquad \mathrm{CE} \rightarrow \mathrm{RGDP}\end{array}$} \\
\hline LOG(RGDP) does not Granger Cause LOG(CE) & 2.15887 & 0.1515 & \\
\hline LOG(RE) does not Granger Cause LOG(RGDP) & 14.1150 & 0.0007 & \multirow{2}{*}{ Unidirectional causality } \\
\hline LOG(RGDP) does not Granger Cause LOG(RE) & 1.16712 & 0.2881 & \\
\hline & & & $\mathrm{RE} \rightarrow \mathrm{RGDP}$ \\
\hline LOG(RE) does not Granger Cause LOG(CE) & 0.73768 & 0.3968 & \multirow{2}{*}{ No Causality } \\
\hline LOG(CE) does not Granger Cause LOG(RE) & 2.77104 & 0.1057 & \\
\hline
\end{tabular}

Source: Author, 2019 
The Granger Causality technique was employed to determine the direction of causation (if any) existing between government expenditure and economic growth in Nigeria, the result of which has been presented in Table 5. The results reveal a unidirectional causal link running from both capital and recurrent expenditures to real GDP, implying that both capital and recurrent expenditures Granger cause economic growth in Nigeria, thereby lending empirical support to the Keynesian theory. This is in line with the findings of Olayungbo and Olayemi (2018), but in stark contrast with that of Awode and Akpa (2018).

\section{CONCLUSION}

Empirical findings from this study revealed that government expenditure has the potential to bring about growth in the economy. This is evidenced in the Granger causality test result, that showed that a unidirectional causality running from both capital and recurrent expenditures to real GDP exists in Nigeria. This means that real GDP can better be predicted on account of capital expenditure, recurrent expenditure, and real GDP than by using the history of real GDP alone. Findings further revealed that, while recurrent expenditure influences growth positively in Nigeria, capital expenditure, on the other hand, contributes negatively to the growth of the Nigerian economy.

The reason for the negative impact of capital expenditure on economic growth cannot be far-fetched. It should be noted that, by the very nature of capital expenditures, it may take up to several years before they result in positive outcomes. Nevertheless, the result perfectly explains the corrupt nature of the country whereby the capital expenditure has turned into an avenue for mismanagement, embezzlement and fungibility of government funds.

In lieu of the foregoing, this study therefore, strongly recommends the need on the part of the government to ensure that funds intended for capital projects are being used for their real course and not just on some white elephant projects that create avenues for mismanagement of funds. This can be achieved by putting an effective monitoring and evaluation (M\&E) system in place in the way and manner in which government funds are being used. This will serve as a way of not only bringing sanity into the business of governance, but also a way of ensuring prudence in public sector spending so that rising government expenditures can have a positive outcome on the general well-being and by extension, propel growth in the economy. 


\section{REFERENCES}

Abbasov, J. A. \& Aliyev, K. (2018). Testing Wagner's Law and Keeynesian Hypothesis in Selected Post-Soviet Countries, Acta Universitatis Agricuturae et Silviculturae Mendelianae Brunensis, 66(5), pp. 1227-1237

Adekunle, Z. C. (2007). Unraveling the Mystery between Public Expenditure and Growth:

Empirical Evidence from Nigeria. International Journal of Economics, 4(1): 21-31.

Adil, M. H., Ganaie, A. A. \& Kamaiah, B. (2017). Wagner's Hypothesis: An Empirical Verification, IIM Kozhikode Society \& Management Review, 6(1), pp. 1-12

Aigheyisi, O. S. (2013). The Relative Impacts of Federal Capital and Recurrent Expenditures on Nigeria's Economy (1980-2011). American Journal of Economics, 3(5), 210-221.

Akonji, D. R., Olateju, A. O. \& Wakili, A. M. (2013). Nexus between Public Expenditure and Economic Growth by testing Wagner's law Time Series: Evidence from Nigeria. International Journal of Development and Sustainability, 2(4), 2383-2395

Antonis, A., Constantinos, K \& Persefoni, T. (2013). Wagner's Law versus Keynesian Hypothesis: Evidence from pre-WWII Greece, Panoeconomicus, 4, pp. 457-472

Awode, S. S. \& Akpa, E. O. (2018). Testing Wagner's Law in Nigeria in the Short and Long Run. Acta Universitatis Danubius. Oeconomica, 14(7)

Ayinde, K., Kuranga, J. \& Adewale, F. L. (2015). Modeling Nigerian Government Expenditure, Revenue and Economic Growth: Co-integration, Error Correction Mechanism and Combined Estimators Analysis Approach. Asian Economic and Fianancial Review, 5(6), 858-867.

Babatunde, S. A. (2018). Government Spending on Infrastructure and Economic Growth in Nigeria. Economic Research-Ekonomska Istrazivanja, 31(1), 997-1014.

Chang, T., Liu, W \& Caudill, S. B. (2004). A Re-examination of Wagner's Law for Ten Countries bBased on Cointegration and Error-correction Modelling Techniques, Applied Financial Economics, 14 (8), pp. 577-589

Chow, Y., Cotsomitis, J. A. \& Kwan, A. C. C. (2002). Multivariate Cointegration and Causality Tests of Wagner Hypothesis: Evidence form the UK, Applied Economics, 34 (13), pp. 1671-1677

Chude, N. P. \& Chude, D. I. (2013). Impact of Government Expenditure on Economic Growth in Nigeria. International Journal of Business and Management Review, 1(4), 64-71.

Iheanacho, E. (2016). The Contribution of Government Expenditure on Economic Growth of Nigeria Disaggregated Approach. International Journal of Economics \& Management Sciences, 5(5), 1-8.

Kairo, C. I., Mang, N. J., Okeke, A. \& Aondo, D. C. (2017). Government Expenditure and Human Capital Development in Nigeria: An Auto-Regressive Distributed Lagged Model Approach (ARDL). International Journal of Advanced Studies in Economics and Public Sector Management, 5(1), 143-158.

Njoku, C. O., Ugwu, K. E. \& Chigbu, E. E. (2014). Government Public Expenditures: Effect on Economic Growth (The Case of Nigeria, 1961-2013). International Journal of Research in Management, Science \& Technology, 2(1), 16-29.

Olayungbo, D. O. \& Olayemi, O. F. (2018). Dynamic Relationship among Non-oil Revenue, Government Spending and Economic Growth in an Oil Producing Country: Evidence from Nigeria. Future Business Journal 4, 246-260.

Oteng-Abayie, E. F. (2011). Government Expenditure and Economic Growth in Five ECOWAS Countries: A Panel Econometric Estimation, Journal of Economic Theory, 2(3): 11-14

Oyinlola, M. A. \& Akinnibosun, O. (2013). Public Expenditure and Economic Growth Nexus: Further Evidence from Nigeria. Journal of Economics and International Finance, 5(4), 146-154.

Sala-I-Martin, X. and Bairo, R. S. (2012). Public Finance in Model in Economic Growth. The Review of Economic Studies, http://www.jseir,org. 59(4): 645 - 661. 
Udoffia, D. T. \& Godson, J. R. (2016). The Impact of Federal Government Expenditure on Economic Growth in Nigeria (1981-2014). Greener Journal of Social Sciences, 6(4), 092-105

Wagner, A. (1958). The Nature of Fiscal Policy. In R. A. Musgrave, \& A. T. Peacock, Classics in the Theory of Public Finance (pp. 1-8). London: Macmillan. 


\begin{tabular}{|c|c|c|c|}
\hline Year & RGDP & CE (N'Billion) & RE (N'Billion) \\
\hline 1981 & $6.11 \mathrm{E}+10$ & 6.57 & 4.85 \\
\hline 1982 & $5.14 \mathrm{E}+10$ & 6.42 & 5.51 \\
\hline 1983 & $3.55 \mathrm{E}+10$ & 4.89 & 4.75 \\
\hline 1984 & $2.85 \mathrm{E}+10$ & 4.10 & 5.83 \\
\hline 1985 & $2.89 \mathrm{E}+10$ & 5.46 & 7.58 \\
\hline 1986 & $2.07 \mathrm{E}+10$ & 8.53 & 7.70 \\
\hline 1987 & $2.41 \mathrm{E}+10$ & 6.37 & 15.65 \\
\hline 1988 & $2.33 \mathrm{E}+10$ & 8.34 & 19.41 \\
\hline 1989 & $2.42 \mathrm{E}+10$ & 15.03 & 25.99 \\
\hline 1990 & $3.08 \mathrm{E}+10$ & 24.05 & 36.22 \\
\hline 1991 & $2.74 \mathrm{E}+10$ & 28.34 & 38.24 \\
\hline 1992 & $2.93 \mathrm{E}+10$ & 39.76 & 53.03 \\
\hline 1993 & $1.58 \mathrm{E}+10$ & 54.50 & 136.73 \\
\hline 1994 & $1.81 \mathrm{E}+10$ & 70.92 & 89.97 \\
\hline 1995 & $2.85 \mathrm{E}+10$ & 121.14 & 127.63 \\
\hline 1996 & $3.50 \mathrm{E}+10$ & 212.93 & 124.49 \\
\hline 1997 & $3.58 \mathrm{E}+10$ & 269.65 & 158.56 \\
\hline 1998 & $3.20 \mathrm{E}+10$ & 309.02 & 178.10 \\
\hline 1999 & $3.59 \mathrm{E}+10$ & 498.03 & 449.66 \\
\hline 2000 & $4.64 \mathrm{E}+10$ & 239.45 & 461.60 \\
\hline 2001 & $4.41 \mathrm{E}+10$ & 438.70 & 579.30 \\
\hline 2002 & $5.91 \mathrm{E}+10$ & 321.38 & 696.80 \\
\hline 2003 & $6.77 \mathrm{E}+10$ & 241.69 & 984.30 \\
\hline 2004 & $8.78 \mathrm{E}+10$ & 351.25 & $1,110.64$ \\
\hline 2005 & $1.12 \mathrm{E}+11$ & 519.47 & $1,321.23$ \\
\hline 2006 & $1.45 \mathrm{E}+11$ & 552.39 & $1,390.10$ \\
\hline 2007 & $1.66 \mathrm{E}+11$ & 759.28 & $1,589.27$ \\
\hline 2008 & $2.08 \mathrm{E}+11$ & 960.89 & $2,117.36$ \\
\hline 2009 & $1.69+\mathrm{E} 11$ & $1,152.80$ & $2,127.97$ \\
\hline 2010 & $3.69 \mathrm{E}+11$ & 883.87 & $3,109.44$ \\
\hline 2011 & $4.12 \mathrm{E}+11$ & 918.55 & $3,314.51$ \\
\hline 2012 & $4.61 \mathrm{E}+11$ & 874.70 & $3,325.16$ \\
\hline 2013 & $5.15 \mathrm{E}+11$ & $1,108.39$ & $3,214.95$ \\
\hline 2014 & $5.68 \mathrm{E}+11$ & 783.12 & $3,426.94$ \\
\hline 2015 & $4.81 \mathrm{E}+11$ & 818.35 & $3,831.98$ \\
\hline 2016 & $4.87 \mathrm{E}+11$ & 613.25 & $4,108.31$ \\
\hline
\end{tabular}

Source: CBN Statistical Bulletin 


\section{UVEĆANA POTROŠNJA VLADE U NIGERIJI: POSTOJI LI POVEZANOST SA NAPRETKOM?}

\section{Rezime:}

Ovaj rad nastoji da utvrdi da li su i kakav uticaj troškovi vlade u Nigeriji imali na rast privrede u toj zemlji, primarno se usmeravajući na kapitalne i stalne trškove vlade, koji su uticali na stvarni bruto domaći proizvod (BDP). Sekundarni podaci u vidu vremenskih serija - iz perioda 1981 - 2016, preuzeti iz Statističkog biltena CBS (Centralnog biroa za statistiku), upotrebljeni su za ove namene. Nakon što je utvrđeno da su navedene serije, u dužem intervalu, bile u kointegraciji sa pripadajućom tehnikom Johansena, u istraživanju je upotrebljena ispravka grešaka (error correction), kao i Grejndžerov test uzročnosti (Granger causality test), kako bi se postigli postavljeni ciljevi. Rezultati ukazuju na to da stalni troškovi imaju značajan pozitivan uticaj na stvarni BDP, dok je uticaj kapitalnih troškova na BDP negativan. Grejndžerov test uzročnosti otkrio je da, kako stalni, tako i kapitalni troškovi utiču na stvarni BDP. Otuda, ovaj rad se zalaže za sistem temeljnijeg praćenja i procene načina na koji se koriste sredstva vlade, posebno ona namenjena kapitalnim projektima, kako bi uticaj na samu privredu bio pozitivan.

Ključne reči:

kapitalni troškovi, ekonomski razvoj, mehanizam ispravke grešaka, Grejndžerova uzročnost, bruto domaći proizvod 